\title{
Politik Santri Dalam Daur Ulang Kontrak Sosial
}

\author{
Abdul Munir Mulkhan
}

The following article tries to trace the reflection regarding santri political world at national stage. The groups of santri believe that they are as representatives of moslem communities although that fact shows that the groups of santri always fail to get full supporting from moslem majority. Democracy places the voice of majority as the truth source that handled by the people. This principle of democracy can not be understood that contrary to the the doctrine system of Islam when moral quality of political party leaders, that of legislative, that of the candidate of president and that ot vice president.

T ulisan ini merupakan sebuah refleksi tentang perpolitikan santri dalam pentas politik nasional. Politik santri adalah sebutan bagi kegiatan politik yang dilakukan aktjvis politik dari komunitas yang selama ini dikenal lebih taat pada berbagai aturan dalam sistem ajaran Islam (Geertz, 1983). Kaum santri sering mengklaim mewakili suara mayoritas rakyat yang mayoritas memeluk Islam walaupun hampir selalu gagal merebut simpati mayoritas pemilih di sepanjang pemilihan umum (Pemilu) yang pernah diselenggarakan di negeri ini.

Kaum santri meyakini sebagai kelompok yang teguh pada nilai-nilai moral yang bersumber ajaran agama (Islam). Sementara kualitas moral dan profesional dari calon anggota legislatif (caleg), calon presiden (capres) dan calon wakil presiden (cawapres) sering bukan satu-satunya prasyarat terpilih dalam Pemilu demokratis. Kemampuan sang calon dalam berkomunikasi dengan mayoritas pemilih sering lebih manjur bagi caleg, capres dan cawapres untuk bisa terpilih dalam suatu pesta demokrasi. Selain itu yang tak boleh dilupakan ialah citra partai yang mencalonkan sang caleg, capres dan cawapres di mata rakyat pemilih. Melalui proses panjang dengan beragam media dalam membangun komunikasi dialogis, suatu partai, dan caleg atau capres dan cawapres akan bisa menjadi bagian integral dari keseharian hidup massa pemilih.

Kecenderungan di atas penting menjadi cacatan politisi dan partai berlambang Islam atau berbasis komunitas Muslim (selanjutnya disebut politisi dan partai santri). Pemahaman terhadap berbagai persoalan tersebut merupakan kunci dan titik awal bagi caleg, capres dan cawapres, terutama yang berbasis kesantrian, memperoleh dukungan dari mayoritas pemilih. Sebaliknya, kegagalan memahaminya akan merupakan faktor utama kekalahan partai dan politisi santri memperoleh dukungan mayoritas rakyat. 
Kebaikan moral dan keadilan yanǵ bersumber nilai keagamaan merupakan tema utama yang menjadi isu kampanye partai dan politisi santri. Namun demokrasi bukan jalan utama tanpa simpangan bagi pengembangan kebaikan moral dan keadilan. Bukan karena mayoritas rakyat pemilih abai pada kebaikan moral dan keadilan, namun tema-tema tersebut merupakan wacana yang terlalu jauh dari hajat keseharian hidup rakyat yang mayoritas merupakan warga kebanyakan.

Demokrasi sebagai sistem daur ulang kontrak sosial dan kepemimpinan dalam Pemilu ternyata bukan tidak jalan mencapai perbaikan hidup, bahkan bukan jalan tanpa cacat (lihat Gramsci dalam Patria dan Arief, 1999). Konon demokrasi di negeri ini bahkan telah terjual kepada para pihak yang punya uang dan kekuatan hingga berubah menjadi sebuah pasar dan pertarungan keras. Nilai kedaulatan rakyat menjadi komoditi yang diperjualbelikan yang diperebutkan dengan penuh kekerasan fisik. Sebagai jalan permutuan kehidupan sosial-politik dan ekonomi, demokrasi memerlukan sejumlah persyaratan moral dan sikap kritis rakyat sebagai pemegang kedaulatan yang antara lain ditunjukkan oleh tingkat pendidikannya.

Tanpa komitmen moral dan pendidikan politik bagi rakyat dan pelaku politik, demokrasi bisa berubah menjadi kekerasan dan demoralisasi sistematis. Seperti tesis Nicollo Machiavelli, demokrasi bisa berubah menjadi seekor harimau liar berwajah manusia yang menelan yang lemah dan yang bermoral tetapi tidak punya kehendak kuat untuk berkuasa (Budiardjo, 1988). Etika moral yang sering bersifat elitis dan bertengger di menara gading tidak cukup ampuh menarik simpati publik pemilih yang di negeri ini umumnya terdiri dari kaum buruh, petani, dan nelayan sebagai wong cilik yang tinggal di pedesaan, dan di kawasan kumuh pinggiran kota atau kawasan pantai.

Perjuangan memenuhi kebutuhan hidup keseharian tidak memberikan kesempatan cukup bagi wong cilik untuk berfikir abstrak tentang etika-moral dan nilai transendental keagamaan. Tidak cukup waktu bagi rakyat kebanyakan terlibat aktif dalam berbagai kegiatan keagamaan dan kegiatan ritual yang jauh dari hajat hidup keseharian. Penting bagi kaum moralis dan agamawan untuk menampilkan nilai moral dan keagamaan yang fungsional bagi hajat hidup keseharian publik pemilih (Mulkhan, Moral Politik, 2003). Dari sini kaum moralis dan agamawan baru bisa menghadapkan memperoleh mandat rakyat untuk menata sistem kehidupan sosial, ekonomi dan politik dengan akar moral dan keagamaan yang lebih bermoral dan berketuhanan bagi kebaikan hidup rakyat.

\section{Komposisi Sosial Pemilih dan Kontrak Sosial}

Terdapat tiga kecenderungan partai dan pemilih yang bisa mempengaruhi hasil dan mutu pemilihan umum (Pemilu) 2004 ini. Ketiganya berkaitan dengan persoalanpersoalan seperti; pola perilaku politik pemilih, tingkat kehidupan ekonomi dan pendidikan pemilih, dan agenda atau program kerja partai. Ketiga kecenderungan tersebut sebagian berkaitan dengan kondisi obyektif kehidupan sosial-ekonomi rakyat pemilih (lihat hasil survei dari Lembaga Survei Indonesia, 2004).

Mutu Pemilu sebagian lagi berkaitan dengan mutu partai politik yang antara lain ditunjukkan oleh pola rekruitmen partai, baik rekruitmen anggota, elite pemimpin partai, dan calon anggota legislatif (caleg). Gejala demikian itu antara lain bisa dilihat oleh semakin banyaknya kasus pemalsuan 
ijazah yang dilakukan para caleg dari berbagai partai hanya karena batas minimal pendidikannya tidak memenuhi persyaratan. Sementara pegawai negeri dilarang menjadi pimpinan partai dan caleg, selama pembangunan Orde Baru, masyarakat terdidik pada umumnya terserap dan dimobilisasi ke dalam berbabai unit birokrasi pemerintahan dan guru dalam kedudukan sebagai pegawai negeri (PNS).

Kecenderungan pertama menunjukkan bahwa pola pilih dari publik pemilih di dalam Pemilu 2004 ini belum berbeda secara signifikan dibandingkan Pemilu-Pemilu sebelumnya. Secara umum, pilihan politik (partai) publik pemilih didasari pertimbangan kedekatan hubungan antara rakyat pemilih tersebut dengan elite partai di mana rakyat tinggal menetap. Seseorang cenderung memilih partai tertentu bukan didasari oleh suatu pertimbangan rasional dalam arti bahwa ia memilih partai, caleg, dan capres karena diyakini akan dan bisa mengubah nasibnya dan mengubah tatanan politik kebangsaan.

Karena itu, tindakan mencoblos partal tertentu juga bukan didasari kesepakatan rakyat atas ideologi partai dan atau program partai bersangkutan, bukan pula karena seorang caleg atau capres dan cawapres diyakini akan membawa perubahan nasibnya. Lebih jauh lagi pertimbangan bahwa partai, caleg, capres dan cawapres itu dipilih karena akan membawa kebaikan bagi kehidupan bangsa dan negara. Gejala politik yang bisa disebut demokrasi semu, kepalsuan demokrasi atau gejala pragmatisme politik bagi mayoritas pemilih. Bagaimana pun kecenderungan tersebut merupakan fakta yang penting dicermati semua pihak, terutama elite partai dan semua kekuatan bangsa ini.

Jika kaum santri atau nasionalis dipandang sebagai kelompok paling sadar atas pilihan politiknya di atas basis ideologi islami atau nasionalis, tidak seluruhnya terlihat di lapangan. Contoh paling jelas ialah sulitnya bagi partai-partai yang mengusung romantisme Masyumi memperoleh dukungan signifikan dalam pemilu demokratis pasca reformasi. Demikian pula tetap bertenggernya Golkar di urutan kedua sesudah jatuhnya Orde Baru yang semula berbasis Golkar. Hasil survei Lembaga Survei Indonesia juga menunjukkan kecederungan romantisme Orde Baru bagi sebagian pemilih. Hal ini bisa dilihat dari tampilnya Partai Karya Peduli Bangsa (PKPB) dengan jelas-jelas berjuang dan berusaha menghadirkan kembali model politik Orde Baru yang dalam tempo singkat memperoleh apresiasi publik sehingga lolos persyaratan untuk ikut dalam Pemilu 2004.

Kedua, pola perilaku politik rakyat pemilih berkaitan dengan tingkat pendidikan dan tingkat kehidupan ekonomi. Mayoritas rakyat pemilih di negeri ini terdiri dari rakyat yang berpendidikan paling tinggi tamat SLTP. Dari mereka yang paling tinggi tamat SLTP itu mayoritas paling tinggi tamat $S D$ dan mayoritasnya lagi tidak tamat SD. Publik pemilih di negeri ini sebagian besar terdiri dari kaum petani, buruh dan nelayan dan tinggal di pedesaan, kawasan kumuh di pinggir-pinggir kota dan kawasan pantai. Kesibukan sehari-hari pemilih ialah berjuang memenuhi kebutuhan makan yang jauh dari persoalan-persoalan politik formal (Mulkhan, Islam Murni, 2000).

Ideologi, dengan corak apa pun, secara akademik memang semestinya mewarnai partai-partai politik peserta Pemilu. Namun ketika suatu partai mengklaim berbasis ideologi tertentu, program dan agenda partai itu seperti tidak mencerminkan akar ideologisnya. Ideologi partai seringkali lebih sebagai simbol partai yang segera hilang dalam hampir keseluruhan kegiatan partai. 
Bagi mayoritas rakyat di negara berkembang seperti Indonesia ini, ideologi adalah merupakan barang mewah.

Sementara itu, nilai moral dan teks sucj keagamaan yang secara tradisional menjadi ciri khas partai berbasis keagamaan, sulit untuk masuk dalam kesadaran hidup rakyat kebanyakan tersebut. Mereka memiliki konsep yang khas tentang ideologi dan keagamaan yang tak jauh dari tesis Karl Marx tentang kebutuhan dan hajat hidup keseharian (Hamersma, 1983). Ideologi dan keagamaan rakyat itu tumbuh secara alami sebagai bagian dari keterperangkapan mereka dalam dinamika alam yang keras dan yang sering diperkeras oleh sistem sosial, ekonomi dan politik yang tak berpihak kepada rakyat kecil tersebut.

Ketiga, partai-partai peserta Pemilu belum memiliki agenda yang jelas selain akar ideologi yang cenderung menghilang dalam kinerja partai. Program dan agenda yang relatif kongkrit bagi kepentingan publik rakyat sebagai mayoritas pemilih pun sulit ditemukan. Pemilu cenderung dibelokkan menjadi instrumen mobilitas sosial dan ekonomi yang sering disebut sebagai pekerjaan di tengah sulitnya mencari lapangan kerja. Di sinilah muncul gejala premanisme politik dalam banyak kegiatan partai.

Di sisi lain, hampir seluruh partai dibentuk di Jakarta. Sesudah suatu partai dideklarasikan, barulah kemudian disosialisasikan ke daerah dan seterusnya ke lapisan rakyat kebanyakan. Kecenderungan elitis ini juga bisa dilihat dari berbagai gerakan sosial dan keagamaan. Rakyat pemilih yang secara akademik dan moral sebagai pemegang dan pemilik kedaulatan dalam sistem demokrasi, tak ubahnya menjadi komoditi partai sekaligus konsumen yang segera dilupakan begitu Pemilu usai.
Karena itu tingginya jumlah rakyat pemilih ke tempat-tempat pemungutan suara (TPS) sulit dijadikan ukuran kualitas partisipasi rakyat dalam Pemilu (Liddle, 1992). Bisa diduga rakyat pemilih yang mendatangi tempat-tempat pemungutan suara (TPS) jumlahnya cukup besar konon terbesar di kolong jagad. Namun angkaangka itu tidak bisa dijadikan petunjuk bahwa tingkat partisipasi rakyat terhadap penyelenggaraan pemilihan umum (Pemilu) berarti tinggi. Kualitas partisipasi terhadap Pemilu berkaitan dengan hasil Pemilu yang secara universal merupakan instrumen bagi pengembangan mutu kehidupan rakyat dan umat manusia. Partisipasi rakyat dalam Pemilu perlu dilihat dan diukur kemampuan Pemilu mengubah penyelenggaraan negara dan pemerintahan yang lebih baik dalam arti lebih memperhatikan kepentingan publik rakyat tersebut.

Persoalan partisipasi rakyat terhadap Pemilu di atas berkaitan dengan kemampuan partai-partai politik dalam melakukan pendidikan politik bagi rakyat pemilih secara keseluruhan selain terhadap anggotanya sendiri. Di satu sisi pendidikan politik membuat mutu partisipasi anggota dan rakyat meningkat dan kritis yang selanjutnya merupakan bahan dasar bagi peningkatan mutu partai. Namun di sisi lain, mutu partispasi dan sikap kritis anggota dan masyarakat secara keseluruhan terhadap kegiatan politik, khususnya partai, bisa mempersulit elite partai mengeluarkan berbagai kebijakan partai tanpa kritik anggta dan masyarakat. Di sinilah partai politik menghadapi dilema antara kebutuhan peningkatan mutu partai dan sikap da partsipasi kritis anggota dan masyarakat terhadap partai bersangkutan.

Sistem Pemilu kali ini memang secara teoretis menempatkan rakyat pemilih bisa 
memilih secara langsung calon anggota legislatif selain partai. Demikian pula dengan calon anggota Dewan Perwakilan Daerah (DPD) dan Presiden dengan pasangan Wakil Presidennya. Namun keterlambatan atau keengganan partai melakukan sosialisasi membuat hasil Pemilu 2004 ini tak akan banyak berbeda dengan Pemilu 1999 yang lalu.

Di satu sisi, sistem daftar terbuka dalam penyusunan daftar caleg secara teroretis memang seharusnya akan menghasilkan anggota legislatif yang lebih bermutu dan lebih baik dalam arti lebih sesuai kehendak rakyat. Namun ketiadaan atau kurangnya informasi tentang tata cara Pemilu legislatif dan Presiden dengan Wakil Presidennya, membuat pilihan rakyat dalam Pemilu itu menjadi sebuah tebakan tanpa referensi. Di sisi lain, orientasi rakyat pemilih terhadap caleg pilihannya bisa mengurangi wibawa partai yang tak mudah diterima elite partai peserta Pemilu.

Karena itu kontrak sosial-politik yang mestinya mengalami daur ulang di dalam setiap penyelenggaraan Pemilu menjadi sebuah ilusi dan mimpi indah di siang bolong yang membuat setiap orang tergagap-gagap begitu melihat kinerja anggota partemen dan kabinet pemerintahan yang terbentuk hasil Pemilu tersebut. Pemilihan Presiden dan Wakil Presiden secara langsung memang memberi mandat kuat kepada'kabinet yang dibentuk sang presiden terpilih. Namun tanpa mekanisme kontrol yang mampu bekerja efektif, presiden yang kuat itu dikhawatirkan bisa bertindak otoriter dan arogan dengan bertopeng demokrasi.

Bersamaan itu sang parlemen bisa menikmati fasilitas yang diperoleh dengan menjual kekuasaan yang ada pada dirinya melalui undang-undang dalam bentuk APBN (anggaran pendapatan dan belanja negara) yang disusun pemerintah bersama parlemen. Hal yang sama bisa dilakukan kepala daerah (bupati, walikota atau gubernur) ketika parlemen daerah melakukan hal serupa melalui APBD (anggaran pendapatan dan belanja daerah). Gejala inilah yang belakangan disebut sebagai gejala desentralisasi dari praktik KKN (kolusi, korupsi dan nepotisme) secara legal sebagai hasil paling riel dari reformasi. KKN yang semula terpusat dan relatif terkendali dari pusat ibukota, kini terus meluas ke seluruh jajaran birokrasi pemerintahan bersama parlemen daerah.

Bukan berarti rakyat pemilih tidak cerdas dan tidak memiliki kearifan kedaulatan ketika publik rakyat tersebut seperti membisu dan diam. Namun ketiadaan sistem yang bekerja efektif, membuat mereka seperti kehilangan media melakukan kontrol yang secara sistematis dan legal telah dipasung oleh partai politik. Kebuntuan aspirasi rakyat yang jika terus meluas itulah yang beberapa waktu lalu dihawatirkan oleh banyak ahli sosial bisa membuahkan revolusi sosial. Sekurangnya pertuasan gejala tersebut bisa menimbulkan pembangkangan sosial secara semu yang muncul dalam bentuk anarkisme sosial di berbagai belahan negeri ini.

Realitas politik di atas penting dicermati bagi kaum moralis yang memandang diri paling berhak memimpin negeri yang mengklaim diri sebagai bangsa religius ini. Tanpa mandat dari publik pemilih sulit bagi mereka menunjukkan bukti komitmennya pada nilai keadilan, kesejahteraan bagi semua dan kebaikan moral di atas kepentingan rakyat, bangsa dan kemanusiaan. Soalnya terletak pada bagaimana kaum moralis itu memahami perilaku politik publik pemilih dan menyusun strategi yang mampu bekerja efektif sehingga memperoieh dukungan mayoritas rakyat: 


\section{Partai dan Presiden Populis}

Hukum besi politik dan demokrasi di atas juga berlaku bagi kaum santri yang sering mengklaim mewakili mayoritas pemilih yang mayoritas memeluk Islam. Mereka harus bersedia meninggalkan gagasan abstrak yang diyakini bersumber dari wahyu Tuhan. Sepanjang gagasan abstrak yang diyakini benar tersebut tidak menyentuh hajat hidup keseharian rakyat, sulit bagi kaum santri membuktikan kebenaran keyakinannya. Kebenaran agama menjadi penting dikomunikasikan kepada publik sesuai logika dan bahasa publik. Jaminan kesejahteraan hidup di dunia dan di akhirat sesudah kematian periu diterjemahkan ke dalam sistem sosial, ekonomi dan politik yang mampu bekerja efektif, sehingga rakyat kebanyakan itu bisa memenuhi hajat hidup kesehariannya.

Karena itu, peta politik. nasional menunjukkan tidak berubah banyak. sesudah kasasi yang diajukan oleh Akbar Tanjung dikabulkan Mahkamah Agung (MA). Keputusan MA ini lebih besar pengaruhnya terhadap proses pencalonan presiden dalam konvensi Golkar. Posisi partai Golkar pun tak banyak berubah dalam perolehan suara dalam Pemilu 2004, walaupun banyak pihak tidak puas terhadap keputusan MA tersebut. Romantisme (kerinduan masa lalu) dari rakyat kebanyakan terhahap Orde Baru, ketika gerakan reformasi belum juga berhasil menyelesaikan berbagai krisis ekonomi, justru bisa membuat perolehan suara Golkar tersebut meningkat.

Sementara PDI-P diuntungkan oleh posisinya-sebagai penguasa, partainya kaum santri tampaknya tetap sulit memperoleh dukungan mayoritas pemilih. Sepanjang partai santri tersebut bersama gerakan Islam kurang peduli pada nasib rakyat yang petani, buruh, dan nelayan, sulit bagi partainya kaum santri untuk memperoleh dukungan mayoritas rakyat pernilih (Mulkhan, Mitos, 1994; Moral Politik, 2003). Peluang bagi capres santri dengan pasangan cawapresnya untuk memperoleh dukungan rakyat tampaknya kurang lebih serupa dengan nasib partainya kaum santri.

Dukungan rakyat akan lebih terbuka sepanjang partai santri dan sang capres dari kaum santri berhasil menjadi bagian integral kehidupan wong cilik. Identifikasi partai dan capres sebagai bagian dari kehidupan pemilih sering lebih manjur dalam menarik simpati dari rakyat pemilih. Secara teoretis ketika mayoritas pemilih mayoritas memeluk Islam, simbol-simbol Islam yang melekat pada partai santri dan capresnya lebih mudah membangun kesepadanan identitas. Sayangnya simbol-simbol tersebut belum dengan cerdas diterjemahkan sesuai bahasa rakyat yang populis, sehingga jauh dari kultur keseharian mayoritas pemilih. Retorika intelektuál, platform dan program partai atau capres, memang menarik bagi kalangan akademisi dan kelas elite, tapi kurang populer bagi sebagian besar masyarakat pemilih.

Kegagalan partai santri dan capresnya memperoleh dukungan mayoritas, bukan karena partai itu buruk, calegnya busuk, capresnya tidak bersih dan tidak intelektual. Kegagalan tersebut lebih disebabkan oleh karena kaum santri gagal menterjemahkan ajaran Islam dan berbagai simbol darinya ke dalam agenda dan program fungsional bagi kepentingan praktis mayoritas rakyat yang disosialisasikan sesuai bahasa dan logika publik rakyat. islam seringkali ditampilkan dalam bahasa elite yang normatif (baca; syariah atau fikih) yang tidak sesuai dengan kultur dan keseharian hidup mayoritas rakyat yang sulit dipahami oleh logika wong cilik. 
Ide hubungan organik kemusliman dan partisipasi partai Islam, berakibat sulitnya aktivis santri memahami perilaku politik pemilin Muslim sendiri. Sementara pandangan bahwa kemusliman identik dengan komitmen atas hukum dan ritual Islam (baca; fikih), berakibat agenda dan program partai santri gagal menyentuh hajat hidup keseharian mayoritas rakyat yang Muslim itu sendiri. Kaum santri yang minoritas (sekitar $20 \%$ ) dari $88 \%$ penduduk Muslim sering dan mudah mengklaim dirinya sebagai representasi keseluruhan pemeluk Islam yang mayoritas tergolong abangan. Akibatnya, kekalahan partai santri dan capresnya cenderung dipahami sebagai konspirasi kekuatan anti-lslam, tapi sulit dipahami akibat kegagalan partai santri dan gerakan Islam membangun hubungan fungsional dan kultural dengan mayoritas rakyat kebanyakan (Mulkhan, Mitos, 1994).

Oleh karena itu, kategorisasi keagamaan Clifford Geertz (1983; santri, abangan, priyayi), walaupun tidak bebas kritik, penting dijadikan referensi dalam perumusan agenda dan program partai santri dan capresnya bagi kepentingan rakyat banyak dan bagi kelangsungan Indonesia sebagai bangsa. Pendekatan budaya yang lebih mengedepankan agenda bagi kepentingan pragmatis hajat hidup keseharian orang banyak, akan menumbuhkan hubungan dialogis dan fungsional kaum santri dengan kaum abangan. Ketika jarak kultural santri dan abangan itu mencair, peluang bagi partai santri dengan capresnya dan gerakan Islam untuk memperoleh dukungan mayoritas rakyat akan terbuka lebar (Mulkhan, Moral Politik, 2003).

Perilaku sosial-ekonomi, terutama politik, dari mayoritas rakyat yang abangan bukanlah didasari suatu kerangka nilai ideologis; islami, sekuler atau nasionalis.
Kemanfaatan praktis bagi hajat hidup keseharian dan identifikasi diri sebagai bagian sebuah komunitas besar partai, adalah basis utama ideologi (kalau bisa disebut ideologi) perilaku politik mayoritas pemilih di negeri yang penduduknya mayoritas memeluk Islam. Sayangnya hal ini kurang memperoleh perhatian serius aktivis santri. Fungsi rahmatan lil alamin ajaran Islam lebih sebatas wacana ketika mayoritas rakyat yang abangan cenderung memahami Islam sebagai ajaran serba melarang dan mengancam dengan segala macam hukuman sosial dan teologis. Bukan karena ajaran ini harus ditanggalkan, namun persoalannya terletak bagaimana ia dikomunikasikan sesuai bahasa, logika dan kultur rakyat kebanyakan yang populis.

Partai yang lebih dikenal sekuler atau nasionalis sebenarnya tidaklah memiliki agenda dan program yang benar-benar menguntungkan bagi hajat hidup keseharian dari mayoritas rakyat. Namun, komunikasi yang dibangun dengan bahasa publik dan populis dari partai-partai tersebut, sengaja atau mengalir alamiah, tampaknya lebih sesuai dan mudah dicerna dalam logika wong cilik. Bisa dimengerti mengapa partai sekuler atau nasionalis, lebih sukses merebut simpati mayoritas pemilih Muslim di seluruh Pemilu. Mudah diduga jika PDI-P atau Golkar masih merebut posisi pertama dan kedua perolehan suara dalam Pemilu kedua dalam era reformasi ini.

Dalam Pemilu 2004 terdapat enam partai berbasis Islam, berbasis komunitas Muslim, atau moral Islam (tertutup atau terbuka) sebagai peserta, yaitu: PPP, PBB, PKS, PBR, PPNUI, PKB dan PAN (Republika, 13/1/2004 hlm 12). Partai-partai santri ini memiliki hubungan ideólogis dengan partai Islam peserta Pemilu 1955, seperti; Masyumi, NU, PSII, dan partai Is- 
lam lain. Secara tradisional partai santri itu śering dikelompokkan ke dalam kategori modernis dan tradisionalis (Deliar. Noer, 1987). Isu-isu politik yang dikembangkan di masa reformasi ini ternyata belum banyak berubah dari isu-isu Islam konvensional yang normatif dan verbalistis di masa lalu.

Karena itu, di balik optimisme partaipartai kaum santri bisa meraih dukungan mayoritas pemilih, hanya dalam Pemilu 1955 partai santri bisa mencapai prestasi tertinggi di sepanjang Pemilu yang pernah diselenggarakan di negeri ini. Prestași yang belum menembus angka $50 \%$ pemilih yang ketika itu sekitar $95 \%$ memeluk Islam itu (Deliar Noer, 1987) terus terpuruk dalam beberapa kali penyelenggaraan Pemilu selama Orde Baru (Liddle, 1992). Perolehan suara $33,7 \%$ (12,6 \% PKB; 10,7 \% PPP; $7,1 \%$ PAN; $1,9 \%$ PBB; $1,4 \%$ PKJPKS; Lembaga Survei Indonesia, 2004; Litbang Kompas, 2000) dalam Pemilu 1999 agaknya sulit dipertahankan. Dalam Pemilu 2004 bisa diduga kuat partainya kaum santri (peserta Pemilu 1999 ditambah partai baru santri) paling beruntung hanya akan memperoleh suara sebanyak perolehan suara dalam Pemilu 1999, bahkan mungkin lebih rendah lagi.

Situasi kurang menguntungkan tersebut antara lain disebabkan karena partainya kaum santri tersebut hampir tidak memiliki agenda baru yang relevan bagi kepentingan dan hajat hidup keseharian mayoritas pemilih. Selain itu partainya kaum santri tersebut cenderung berebut suara di kandang sendiri (dalam komunitas santri). Dalam beberapa hal kecenderungan demikian justru bisa menuai konflik di internal komunitas santri itu sendiri. Dari sini bisa dimengeri kesulitan partainya kaum santri tersebut membangun koalisi dan saling kesepahaman di antara mereka, termasuk dalam pencalonan capres dan cawajóres.

Problem partainya kaum santri fersebut di atas tampak juga akan dihadap capres dengan cawapres berbasis kesantrian. Capres santri sulit keluar dari kandang dan habitat kesantrian, sehingga kurand populer di mata wong cilik yang medupakan mayoritas dari publik pemilih. Capres dari partai berbasis NU lebih berpeluang membangun hubungan kultural dal? dialogis dengan abangan dan wong cilik. Sajang dari komunitas ini belum tampil tokoh baru populis yang laku keras dijual, kecuali tokoh sekaliber Gus Dur (mantan presiden ke-4) yang belakangan banyak menghadapi kendala fisik, selain konflik di interna partai. Pemilihan presiden dan wakil presiden secara langsung dalam Pemilu 2004/'tidak seperti selama ini dipilih elite politisi diMPR, lebih mempersulit capres santri merebut simpati pemilih yang abangan, petani, buruh, nelayan dan profesional.

Tema kampanye sesunggunya tidak lebih penting daripada usaha membangun komunikasi kultural dengan retorika populis dengan keluar dari logika dan kultur kesantrian. Reformasi politik dan ekonomi, pemerintahan bersih dan bebas korupsi, merupakan wacana yang penting dan menarik secara akademik. Namun, isu ini terlalu mewah bagi mayoritas rakyat pemilih, selain kurang populer bagi birokrat dan profesional yang selama ini bergelimang $\mathrm{KKN}$. Isu dan tema tersebut lebih populer bagi kalangan intelektual dan mahasiswa yang jumlahnya relatif kecil di antara pemilih yang buruh, petani dan nelayan. Karena itu capres dan pasangan cawapres yang lebih dekat dengan kultur abangan yang mampu tampil populis jauh lebih populer dan diduga kuat akan muncul sebagai pemegang posisi teratas dalam putaran pertama pemilihan presiden dan wakil presiden. 
Berdasar prakiraan hasil Pemilu 2004 dan sesuai Undang-Undang Nomor 23 Tahun 2003 tentang Pemilihan Umum Presiden dan Wakil Presiden, kemungkinan besar hanya muncul 3 (tiga) atau 4 (empat) pasangan capres dan cawapres, yaitu; dari PDI-P dan Golkar, atau gabungan PKB, PPP, PAN, PKS dan PBB atau partai baru (nasionalis, sekuler) lain. Pasangan capres dan cawapres PDI-P diduga kuat akan bisa lolos pada putaran pertama bersama Golkar, terutama karena kasasi ketuanya dikabulkan Mahkamah Agung. Hukum haram bagi pemimpin perempuan memang bisa mengancam capres PDI-P, tapi tema ini hanya efektif bagi kalangan santri, sebaliknya bisa menjadi bumerang di tengah maraknya isu kesetaraan jender. Posisi capres PDI-P dan Golkar baru bisa terancam ketika seluruh partai santri bergabung mencalonkan pasangan capres tunggal. Sayang, gabungan (koalisi) partainya kaum santri tersebut konon hampir mustahil bisa direalisasikan.

Karena itu skenario lolos putaran pertama pemilihan presiden bagi capres dan cawapres santri, tampak tidak mudah diwujudkan. Peluang capres dan cawapres santri dari PKB, PPP, PAN, PKS, PBB, $P B R$, atau yang lainnya, untuk bisa lolos pada putaran pertama banyak ditentukan kemampuannya untuk tampil populis sehingga bisa meyakinkan dan memperoleh dukungan komunitas abangan. Lebih strategis jika capres dan cawapres santri bersama partai santri tersebut membangun saling kesepahaman dengan kaum nasionalis dan sekuler untuk tampil berpasangan:

Selain kemampuan berbicara dengan bahasa rakyat, penting bagi capres dan cawapres santri mengedepankan tema-tema populis. Ekonomi kerakyatan humanis, penciptaan lapangan kerja di sektor infor- mal, pendidikan murah di tingkat dasar dan menengah, selain perdamaian dan keamanan, merupakan suatu agenda penting dan strategis, selain otonomi daerah yang lebih luas. Namun yang segera harus disadari ialah bagaimana partai dan capres santri merebut simpati intelektual dan profesional muda serta wong cilik.

Ketika rakyat pemilih cenderung tak acuh pada gerakan anti korupsi atau anti politisi busuk, seperti dicermati dari hasil survei yang dilakukan Lembaga Survei Indonesia, diperlukan tokoh moral populis yang mampu berbicara dengan bahasa dan logika rakyat kebanyakan atau wong cilik. Sikap tak acuh bukan karena rakyat tersebut memang menyukai koruptor dan politisi busuk, tetapi karena gerakan itu tidak menyentuh langsung kepentingan rakyat pemilih.

Tampil dengan bahasa populis bukan tanpa resiko bagi aktivis dan capres santri ketika ia harus meninggalkan (menunda) tradisi kesantriannya. Namun strategi ini penting guna memperoleh mandat rakyat bagi penumbuhan kehidupan lebih bermoral, sejahtera, adil dan bermartabat sebagaj realisasi praksis rahmatan Iil alamin ajaran Islam dan risalah kenabian. Bukankah mayoritas rakyat negeri ini masih tergolong umat dakwah dimana aktivis santri secara teologis berkewajiban mentransformasikan mereka pada tahap umat ijabah. Pada tahapan ijabah tersebut barulah bahasa dan logika fikih fungsional dan relevan digunakan. Seluruhnya terpulang kepada aktivis santri itu sendiri bagaimana harus memahami diri sendiri dan mayoritas rakyat yang mandat mereka diperlukan.

\section{Penutup}

Demokrasi meletakkan suara mayoritas sebagai sumber kebenaran 
tempat kedaulatan rakyat tertinggi berada. Prinsip ini tidaklah serta merta harus dipahami sebagai bertentangan dengan sistem kebenaran dalam ajaran agama (Islam) ketika kualitas moral elite partai, caleg, capres dan cawapres bersama publik pemilih bisa dirujukkan pada nilaj-nilai dari ajaran keagamaan. Islam sendiri mengenal apa yang disebut ijmak ulama dan prinsip atau teori mutawatir dalam periwayatan hadits yang meletakkan suara mayoritas lebih baik, lebih benar, dan lebih bisa dipercaya daripada suara minoritas.

Doktrin klasik tentang keburukan yang terorganisir lebih berpeluang memperoleh kemenangan daripada kebaikan yang tak terorganisir, mungkin menarik dicermati bagi aktivis dan elite partainya kaum santri. Tidak kalah penting ialah kesediaan memahami doktrin lebih klasik bahwa suara rakyat adalah sebagai suara Tuhan. Doktrin ini bisa merupakan suatu petunjuk teologis bahwa pemihakan kaum santri kepada mayoritas pemilih wong cilik yang walaupun tergolong abangan merupakan bagian dari usaha mendengar dan menjemput suara Tuhan.

Dalam hubungan itulah dialog mistis Nabi Musa dan Nabi Khidlir tentang amal yang langsung diterima Tuhan lebih penting dijadikan referensi bagi pengembangan strategi memenangkan rakyat dan merebut simpati rakyat. Ketika Khidlir mengajukan pertanyaan tentang amal yang langsung diterima Tuhan, jawaban Nabi Musa lebih ditujukan pada ritual formal; salat, puasa, haji dan semacamnya. Ketika jawaban ini ditolak dan jawaban-jawaban lain tak lolos, Musa pun meminta Khidlir menjelaskan. Nabi Khidlir pun menjelasskan bahwa karena ritual formal tersebut sudah merupakan kewajiban yang lahir dari kehidupan manusia, maka amalan yang langsung diterima Tuhan ialah ketika si santri memberi makan yang kelaparan dan memberi pakaian mereka yang telanjang (baca; wong cilik) (Mulkhan, Burung, 2003. Inilah makna ajaran bahwa allah hanya akan menolong hambanya yang memberikan hidupnya untuk menolong sesama (innallaha $f i$ 'auni al-'abdi mad daam al-'abdu fi 'auni ahiihi)

Seluruhnya merupakan tanggungjawab kaum santri itu sendiri apakah karena niat memperoleh posisi terdekat Tuhan harus dilakukan dengan tidak peduli nasib rakyat kebanyakan dan tidak peduli kemanusiaan. Pertanyaan lain yang tak kalah penting ialah apakah karena seseorang atau sekelompok orang jarang atau tidak pemah masuk rumah Tuhan (masjid) tidak berhak menerima kebaikan kaum santri. Karena itu narasi wahyu yang menyatakan bahwa kehidupan di bumi ini hanya dikuasai oleh mereka yang saleh (baca; profesional; lihat Surat Al Anbiya ayat 105; wa lagad katabnaa ff alzabuuri min ba'di al-dzikri anna al-ardla yaritsuhaa 'ibaadiya al-shaalihuuna) perlu dipahami sebagai kewajiban kaum santri menterjemahkan berbagai doktrin Islam sehingga benar-benar berfungsi dan bekerja secara efektif bagi kebaikan hidup publik yang ditunjukkan oleh kemampuan mereka memenuhi hajat hidup kesehariannya.

\section{Daftar Pustaka}

Ardiantoro F, Juri (peny), 1999, Transisi Demorasi; Evaluasi Kritis Penyelenggaraan Pemilu 1999, Jakarta: KIPP Jakarta.

Budiardjo, Miriam, 1988, Dasar-Dasar llmu Politik, Jakarta:Gramedia.

Departemen Agama RI, 1984, Alqur'an dan Terjemahnya, Jakarta: Depag RI. 
Topik: Kepemimpinan Nasional Pasca Pemilu 2004

Geertz, Clifford,'1983, Abangan, Santri, Priyayi Dalam Masyarakat Jawa, Jakarta:Pustaka Jaya.

Hamersma, Harry, 1983, Tokoh-Tokoh Filsafat Barat Modern, Jakarta: Gramedia.

Lembaga Survei Indonesia, 2004, Civil Society, Pemilu 2004 Dan Penguatan Rezim Demokrasi, Jakarta.

Liddle, R. William, 1992, Partisipasi \& Partai Politik Indonesia pada Awal Orde Baru, Jakarta:Grafiti 1992, Pemilu-Pemilu Orde Baru; Pasang Surut Kekuasaan Politik, Jakarta:LP3ES.

Litbang Kompas, 2000, Wajah Dewan Penwakilan Rakyat Republik Indonesia Pemilihan Umum 1999, Jakarta: Harian Kompas.

Mulkhan, Abdul Munir, 2000, Islam Murni dalam Masyarakat Petani, Bentang Budaya , Yogyakarta - Jakarta: Ford Foundation. 1994, Runtuhnya Mitos Politik Santri, Yogyakarta:Si Press. .
2003, Moral Politik Santri; Agama dan Pembelaan Kaum Tertindas, Jakarta:Erlangga.

, 2003, Makrifat Burung Surga dan IImu Kasampurnan Syekh Siti Jenar. Yogyakarta:Kreasi Wacana.

Noer, Deliar, 1987, Partai Islam Di Pentas Nasional, Jakarta:Grafiti Pers.

Patria, Nezar \& Andi Arief, 1999, Antonio Gramsci; Negara \& Hegemoni, Yogyakarta:Pustaka Pelajar.

Undang-Undang Republik Indonesia Nomor 22 Tahun 2003, Tentang Pemilihan Umum Presiden dan Wakil Presiden, Jakarta: Partai Amanat Nasional.

Undang-Undang Parpol \& Undang-Undang Pemilu, 2003, Jakarta:Sinar Grafika.

Undang-Undang Republik Indonesia Nomor 12 Tahun 2003 Tentang Pemilu Tahun 2004, 2003, Bandung:Citra Umbara..

Harian Republika, 13 Januari 2004, "Saatnya Partai Berideologi Agama Tampil Sebagai Pemenang." 